\title{
PEREMPUAN ULEE PULO DAN INDUSTRI KECIL BATU BATA: PERAN EKONOMI KELUARGA DAN UPAYA PEMBERDAYAAN
}

\author{
Risna Dewi *), Nur Hazizah, Muklir \\ ${ }^{*}$ Program Studi Administrasi Publik Universitas Malikussaleh, risnadewi@unimal.ac.id
}

\section{ABSTRACT}

Ulee Pulo Village, Dewantara District, North Aceh Regency is a small brick industrial area. This material is needed as a building material. The construction worker/laborer profession is identical to the menial jobs performed by men. However, the brick as a building material is produced by women, such as in Gampong Ulee Pulo. Most of the workers in the small brick industry are housewives who are looking for additional income. But the brick production process is out of date. This makes the bricks produced are of low quality because they are undercooked during firing, crushed, and the thickness is not uniform. This condition encourages BUMG Ulee Pulo to carry out empowerment programs for small industry players and brick workers who are predominantly women. This study describes the role of women and efforts to empower the brick business in Ulee Pulo village. The research method used is qualitative with data collection techniques in the form of interviews, observation, and documentation. The entire data obtained were analyzed in a reduced way, then presented so that it was easy to understand, and conclusions were found. The results showed that the empowerment strategy was carried out through coaching and training of female brick industry workers where the funds were sourced from BUMG Gampong Ulee Pulo.

Keywords: Women, Family Income, Empowerment, Women, Small Industry, Bricks

\section{ABSTRAK}

Gampong Ulee Pulo Kecamatan Dewantara Kabupaten Aceh Utara adalah daerah penghasil batu bata. Material ini dibutuhkan sebagai bahan bangunan. Sebenarnya profesi tukang/buruh bangunan itu sendiri identik dengan pekerjaan kasar yang dilakukan oleh kaum laki-laki. Namun batu bata sebagai bahan material bangunan ternyata diproduksi oleh kaum perempuan seperti di Gampong Ulee Pulo. Sebagian besar pekerja industri kecil batu bata adalah para ibu rumah tangga yang mencari penghasilan tambahan. Tetapi proses produksi batu bata sudah ketinggalan zaman. Hal ini membuat batu bata yang dihasilkan berkualitas rendah karena kurang matang saat pembakaran, hancur, dan tingkat ketebalan tidak seragam. Kondisi ini mendorong BUMG Ulee Pulo melaksanakan program pemberdayaan kepada para pelaku industri kecil dan pekerja batu bata yang notabene didominasi kaum perempuan. Studi ini menggambarkan peran perempuan dan upaya pemberdayaan usaha batu bata di Gampong Ulee Pulo. Metode penelitian yang digunakan adalah kualitatif dengan teknik pengumpulan data berupa wawancara, observasi, dan dokumentasi. Keseluruhan data yang diperoleh dianalisis dengan cara direduksi, kemudian disajikan agar mudah dipahami, dan ditemukan kesimpulannya. Hasil penelitian menunjukkan bahwa strategi pemberdayaan dilakukan melalui pembinaan dan pelatihan pekerja perempuan industri batu bata dimana dananya bersumber dari BUMG Gampong Ulee Pulo.

Kata Kunci: Perempuan, Ekonomi Keluarga, Pemberdayaan, Industri Kecil, Batu Bata 


\section{PENDAHULUAN}

Salah satu material utama bahan bangunan adalah batu bata. Material ini sudah diproduksi oleh manusia selama beberapa abad dengan cara mengolah tanah liat dan membakarnya hingga berwarna kemerahan. Pada wilayah Provinsi Aceh, industri batu bata berkembang di perkampungan karena bidang usaha ini membutuhkan lahan yang luas dan kemudahan akses bahan baku. Salah satu desa di Kabupaten Aceh Utara dimana perekonomian masyarakat banyak bergantung pada produksi batu bata ialah Gampong Ulee Pulo Kecamatan Dewantara.

Seperti umumnya sebuah pabrik, dalam proses produksi batu bata di Gampong Ulee Pulo terjadi pembagian kerja (Durkheim, 1984). Para pekerja terdiversifikasi ke dalam jenis kelamin. Rata-rata pekerja perempuan berperan sebagai pemotong batu bata dan pengangkut dari tempat pemotongan ke dapur pembakaran. Sedangkan pekerja laki-laki berperan sebagai pengolah tanah dan penanggungjawab proses pembakaran. Jumlah pekerja perempuan jauh lebih banyak daripada pekerja laki-laki. Namun keahlian yang dimiliki pekerja perempuan dalam bidang ini dirasa masih kurang. Oleh sebab itu Pemerintah Gampong dan Pemerintah Kecamatan berkepentingan meningkatkan kapasitas pekerja perempuan dalam industri batu bata karena mereka juga dipandang sebagai ujung tombak penggerak perekonomian lokal.

Inti dari pemberdayaan masyarakat adalah bagaimana rakyat dibantu agar lebih berdaya sehingga dapat mengembangkan kemampuan dan potensi yang dimilikinya. Harapannya masyarakat yang berada di bawah garis kemiskinan dapat meningkatkan taraf hidupnya menjadi lebih sejahtera dan tingkat pengangguran pun berkurang (Asnawi \& M Diah, 2013). Salah satu program pemberdayaan perempuan yang dilakukan oleh Pemerintah Kecamatan Dewantara yang berkolaborasi dengan Pemerintah Gampong Ulee Pulo adalah pemberdayaan perempuan pada industri kecil batu bata. Secara garis besar dapat dikatakan bahwa kegiatan pembuatan batu bata di Gampong Ulee Pulo saat ini telah mendorong pertumbuhan ekonomi lokal melalui rantai nilai kegiatan usaha tersebut. Tumbuhnya kewirausahaan dalam industri batu bata telah menciptakan lapangan pekerjaan bagi masyarakat lokal yang didasari oleh adanya pemanfaatan sumber daya alam dan potensi keahlian yang dimiliki.

Kendala yang dihadapi oleh industri batu bata secara umum ada dua macam yaitu kendala dari sumber daya alam dan kendala dari sumber daya manusia. Jika dilihat dari sumber daya alam di saat kemarau tanah liat sebagai bahan baku batu bata sulit didapatkan karena tanahnya keras. Kendala yang kedua yaitu sumber daya manusia yang mana dalam pemberdayaan terdiri dari ibuibu rumah tangga yang rata-rata tingkat pendidikannya rendah.

82 Jurnal Ilmu Sosial dan Ilmu Politik Malikussaleh (JSPM) Volume 2 Nomor 1 Tahun 2021 
Ditilik dari aspek sumber daya manusia, permasalahan yang terjadi pada industri batu bata Gampong Ulee Pulo yaitu dalam pengolahan batu bata masih menggunakan cara-cara tradisional sehingga banyak batu bata yang memiliki kualitas rendah karena kurang matang saat pembakaran, hancur karena pengolahan tanah sebagai bahan baku kurang maksimal, serta banyak batu bata yang tidak sama tebal tipisnya akibat pengolahan tanah yang kurang baik. Oleh karena itu potensi yang ada di Gampong Ulee Pulo perlu dikembangkan melalui pemberdayaan dengan melakukan pembinaan dan pelatihan agar produk yang dihasilkan lebih laku di pasar dan industri batu bata lebih cepat berkembang dan kompetitif. Berdasarkan uraian di atas, peneliti ingin menggali lebih jauh peran perempuan dalam ekonomi keluarga di Gampong Ulee Pulo dan upaya pemberdayaan yang telah dilakukan oleh pemerintah.

\section{Partisipasi Perempuan dalam Perekonomian}

Sudah tidak diragukan lagi, kaum perempuan mempunyai peran yang sangat besar dalam proses pembangunan di Indonesia. Berbagai studi menunjukkan perempuan terlibat dalam berbagai sektor perekonomian, seperti studi yang dilakukan oleh Rahmaharyati, et al., (2017) yang menemukan bahwa kaum perempuan sudah terbiasa menjalankan peran ganda. Artinya perempuan menjadi ibu rumah tangga (domestik) sekaligus terlibat dalam dunia kerja (publik). Keterlibatan perempuan dalam pemenuhan ekonomi keluarga diteliti oleh Aryani (2017), Husniati, et al. (2018), Tuwu (2018), Tjiptaningsih (2018), serta Suhertina \& Darni (2019). Dengan menggunakan pendekatan kualitatif, studi-studi tersebut menggambarkan betapa strategisnya peran kaum perempuan. Secara mikro, kaum perempuan berkontribusi dalam unit terkecil dari suatu organisasi yang dinamakan keluarga. Maka secara makro atau secara tidak langsung, kaum perempuan sesungguhnya sangat besar kontribusinya bagi pembangunan suatu bangsa. Bila perempuan terlibat dalam pemenuhan ekonomi keluarga secara otomatis gizi anak-anak mereka yang menjadi generasi muda Indonesia juga tercukupi. Begitu pula dengan berbagai indikator makro ekonomi yang lainnya.

\section{METODE PENELITIAN}

Penelitian dilakukan di Gampong Ulee Pulo Kecamatan Dewantara Kabupaten Aceh Utara. Alasan dipilihnya lokasi ini karena terdapat 80 dapur unit industri batu bata dengan pekerjanya yang didominasi oleh perempuan. Penelitian ini menggunakan pendekatan kualitatif deskriptif. Informan atau orang yang memberikan informasi tentang situasi dan latar belakang penelitian (Moleong, 2014) meliputi tiga macam informan yaitu informan kunci, informan tetap, dan 
informan tambahan (Suyanto, 2015). Penentuan informan menggunakan teknik purposive sampling dan snowball sampling sehingga diperoleh data primer. Informan penelitian meliputi: 1) Kepala Bidang Pemberdayaan Masyarakat Disperindagkop Kabupaten Aceh Utara, 2) Sekcam Dewantara Kabupaten Aceh Utara, 3) Keuchik Gampong Ulee Pulo, 4) Sekretaris Gampong Ulee Pulo, 5) Ketua Tuha Peuet Gampong Ulee Pulo, 6) Pendamping Lapangan Kecamatan Dewantara, 7) Ketua PKK Gampong Ulee Pulo, 8) pemilik industri batu bata, dan 9) buruh perempuan yang bekerja di industri batu bata. Data primer juga diperoleh dari observasi. Sedangkan data sekunder diperoleh melalui buku, jurnal, dokumen desa, dan foto. Teknik analisis data yang digunakan dalam penelitian ini adalah model Miles \& Huberman. Langkah-langkah analisis data adalah: 1) mereduksi data, 2) menyajikan data, dan 3) menarik kesimpulan (Sugiyono, 2013).

\section{HASIL DAN PEMBAHASAN}

\section{Peran Perempuan dalam Meningkatkan Pendapatan Keluarga}

Berdasarkan data yang berhasil dihimpun, terdapat 80 dapur industri batu bata di Gampong Ulee Pulo yang terdiri dari 250 sal tempat percetakan. Batu bata tersebut dijual dengan harga Rp. 450,- per batang. Beberapa pemilik usaha industri batu bata adalah perempuan. Sementara pekerja perempuan lebih banyak jumlahnya daripada pekerja laki-laki. Banyak keluarga memperoleh tambahan pendapatan dengan bekerja sebagai buruh di industri pengolahan batu bata. Jumlah pekerja laki laki dari keseluruhan industri batu bata yaitu sebanyak 160 orang dan pekerja perempuan sebanyak 180 orang dari 572 Kepala Keluarga di Gampong Ulee Pulo. Jadi hampir 60 persen keluarga di Gampong Ulee Pulo hidup dari produksi batu bata. Mereka bekerja sebagai buruh kasar dengan upah sebesar Rp. 60,00 (enam puluh rupiah) per batang.

Rata-rata batu bata yang siap dicetak oleh seorang pekerja dalam sehari yaitu antara 600 sampai dengan 800 batang. Besar kecilnya pendapatan yang diperoleh tergantung dari banyaknya batu bata yang berhasil dicetak. Hal ini tentunya berhubungan erat dengan kecepatan dan keterampilan yang dimiliki oleh masing-masing pekerja. Dengan demikian, dapat diperkirakan bahwa pendapatan buruh industri batu bata sekitar Rp. 36.000,- sampai dengan Rp. 48.000,- per hari. Pendapatan ini tentunya masih jauh dari cukup guna memenuhi kebutuhan sehari-hari. Tetapi sebagian buruh perempuan merasa bahwa kegiatan yang mereka lakukan dalam rangka membantu mencukupi kebutuhan keluarga. Sementara tugas pokok dalam aktivitas perekonomian keluarga tetap berada di pundak suami. 
Keberadaan usaha kecil pengolahan batu bata telah berhasil meningkatkan pendapatan, keterampilan, dan kemandirian masyarakat, terutama bagi para ibu rumah tangga. Salah satu pekerja perempuan mengatakan bahwa:

"Usaha batu bata bagi kami adalah bentuk penyokongan ekonomi untuk membantu dalam memenuhi kebutuhan keluarga. Dengan adanya usaha ini pendapatan keluarga tidak hanya semata-mata dari penghasilan suami tetapi juga ada pemasukan dari saya sendiri." (Zubaidah, Gampong Ulee Pulo, 3 Februari 2020).

Keterlibatan perempuan dalam usaha batu bata telah mengubah rutinitas kegiatan ibu rumah tangga. Pola hidup kaum perempuan yang sebelumnya hanya terbatas pada urusan rumah dengan kegiatan yang monoton bergeser ke arah yang lebih produktif. Lebih dari itu, batu bata telah mengubah taraf ekonomi yang menunjukkan meningkatnya kesejahteraan dan status sosial bagi sebagian besar ibu rumah tangga di Gampong Ulee Pulo. Kamariah sebagai salah satu pekerja usaha batu bata mengatakan:

"Usaha batu bata dapat membantu meningkatkan pendapatan, dulu kami hanya mengurus rumah tangga sambil menunggu suami pulang bekerja. Ekonomi keluarga semata-mata dari penghasilan suami, namun dengan adanya pemberdayaan ini, kami sudah mempunyai penghasilan sendiri yang dapat membantu kebutuhan rumah tangga. Pemberdayaan kaum perempuan yang dilaksanakan telah dapat meningkatkan pendapatan keluarga." (Gampong Ulee Pulo, 4 Februari 2020).

Pernyataan di atas dibenarkan oleh Nurlaili selaku Ketua PKK Gampong Ulee Pulo. Informan mengatakan:

“... jelas dampak yang dirasakan terutama bagi ibu-ibu rumah tangga yang dulunya hanya melakukan aktivitas rumah tangga. Ekonomi keluarga semata-mata dari penghasilan suami, namun dengan adanya program pemberdayaan usaha batu bata, ibu-ibu rumah tangga sudah mempunyai penghasilan sendiri yang dapat membantu kebutuhan rumah tangga. Jika dilihat dari ilmu pengetahuan, ibu-ibu rumah tangga sudah mempunyai keterampilan dalam usaha tersebut." (Gampong Ulee Pulo, 2 Februari 2020).

Keterlibatan istri di Gampong Ulee Pulo dalam membantu perekonomian keluarga karena kondisi yang memaksa mereka melakukan hal itu. Bila mengandalkan suami yang bekerja sebagai buruh tani, nelayan, atau buruh bangunan, penghasilan yang didapatkan tidak rutin dan tidak menentu. Maka penghasilan yang diperoleh sebagai buruh industri batu bata sangat menjanjikan karena upah diperoleh harian. Uang yang berhasil didapat pada hari itu digunakan untuk membeli kebutuhan pokok dan uang jajan anak yang sedang sekolah.

Adanya potensi pendapatan keluarga ini mendorong pemerintah setempat melakukan strategi penyokongan. Tujuannya membantu memperkuat kapasitas kaum perempuan dalam memenuhi kebutuhan keluarga. Jadi pendapatan keluarga tidak hanya semata-mata mengandalkan 
penghasilan suami, tetapi juga ada pemasukan dari istri. Apalagi istri juga sudah mempunyai pengalaman tentang usaha batu bata, tapi keterampilannya saja yang perlu ditingkatkan. Hal ini seperti diungkapkan oleh Sekcam Dewantara:

"Selama ini program pemberdayaan perempuan pada usaha batu bata di Gampong Ulee Pulo yang dilaksanakan melalui dana BUMG adalah sebagai bentuk penyokongan dan penguatan ekonomi masyarakat. Dengan adanya program ini pendapatan keluarga tidak hanya semata-mata dari penghasilan suami tetapi juga ada pemasukan dari istrinya. Di samping itu, ibu-ibu rumah tangga juga akan mempunyai pengalaman tentang usaha batu bata..." (M. Zani, Kantor Kecamatan Dewantara, 27 Januari 2020).

Pemberdayaan dalam meningkatkan perekonomian masyarakat menekankan bahwa kaum perempuan dapat memperoleh keterampilan, pengetahuan, dan kekuasaan yang cukup untuk berusaha. Pemberdayaan dilakukan secara bersama-sama pada sebuah kepentingan bersama dengan tujuannya meningkatkan kesejahteraan masyarakat. Keuchik Gampong Ulee Pulo dalam wawancaranya mengungkapkan bahwa memberdayakan masyarakat adalah upaya memperkuat unsur-unsur keberdayaan untuk meningkatkan harkat dan martabat lapisan masyarakat yang berada dalam kondisi tidak mampu dengan mengandalkan kekuatannya sendiri sehingga dapat keluar dari perangkap kemiskinan dan keterbelakangan (Alfiady \& Dewi, 2020). Artinya ada proses memampukan dan memandirikan masyarakat. Masyarakat bisa memanfaatkan dan mengelola dengan baik hasil sumber daya alam di sekitarnya. Program pemerintah hadir sebagai bentuk penyokongan dan penguatan ekonomi masyarakat. Di samping itu, melalui program pemberdayaan perempuan pada usaha batu bata di Gampong Ulee Pulo telah ada upaya memperkuat pengetahuan dan kemampuan yang dimiliki oleh ibu rumah tangga. Sekarang para ibu rumah tangga sudah mengisi waktu luang dengan kegiatan yang bermanfaat untuk keluarganya sekaligus dapat membantu suami dalam mencukupi kebutuhan sehari-hari. Sofyan selaku Sekretaris Gampong mengatakan sebagai berikut:

"Program pemberdayaan perempuan pada usaha batu bata sangat berpotensi untuk mengoptimalisasi kemampuan mereka dan kami mengembangkannya, dan cukup potensial untuk dikembangkan di masa mendatang. Program pemberdayaan yang dilakukan tujuannya untuk penyokongan dan penguatan ekonomi masyarakat." (Gampong Ulee Pulo, 29 Januari 2020).

Strategi pemberdayaan perempuan pada usaha batu bata di Gampong Ulee Pulo dilakukan melalui peningkatan kualitas sumber daya manusia melalui lembaga-lembaga ekonomi lokal. Kualitas sumber daya manusia merupakan faktor penentu produktivitas, baik secara makro maupun mikro. Sumber daya manusia adalah masyarakat yang telah memasuki usia angkatan kerja yang 
memiliki potensi untuk berperilaku produktif dan mampu memenuhi kebutuhan hidup sendiri dan keluarganya. Menurut pendapat salah seorang pemilik usaha batu bata:

"Dampak dari program pemberdayaan ekonomi ini, yang terlihat dalam masyarakat antara lain masyarakat dapat mandiri, mempunyai keterampilan dalam mengolah batu bata, dapat meningkatkan pendapatan keluarga, kehidupan mereka menjadi lebih sejahtera. Walaupun segi produk yang dihasilkan masih tradisional dengan peralatan yang sederhana, selama ini usaha batu bata mampu menunjang penghasilan masyarakat setempat terutama ibu-ibu rumah tangga." (Ruhamah, Gampong Ulee Pulo, 3 Februari 2020).

\section{Bentuk Pemberdayaan Perempuan Ulee Pulo dalam Industri Kecil Batu Bata}

Partisipasi masyarakat dalam proses pembangunan akan terwujud sebagai suatu kegiatan nyata apabila terpenuhi tiga faktor utama yang mendukungnya, yaitu (1) kemauan, (2) kemampuan, dan (3) kesempatan bagi masyarakat untuk berpartisipasi (Sumardjo \& Saharudin, 2003: 34). Maka kapasitas pekerja industri batu bata perlu terus menerus ditingkatkan agar produktivitas dan efisiensi mereka dalam bekerja meningkat pula. Bila batu bata yang dihasilkan lebih baik kuantitas dan kualitasnya tentu saja upah harian yang diperoleh juga semakin baik. Berpatokan pada

keyakinan itu, Pemerintah Kecamatan Dewantara dan Pemerintah Gampong Ulee Pulo melakukan upaya pemberdayaan perempuan pekerja batu bata. Strategi yang ditempuh diantaranya:

\section{a. Pembinaan}

Pembinaan secara umum diartikan sebagai usaha untuk memberi pengarahan dan bimbingan guna mencapai suatu tujuan tertentu. Idealnya strategi pemberdayaan perempuan pada usaha batu bata di Gampong Ulee Pulo dilakukan melalui beberapa tahap antara lain dengan menggali informasi, penetapan prioritas, pengembangan gagasan bersama kelompok sasaran, pemilihan alternatif, perencanaan kegiatan, pelaksanaan kegiatan, pemantauan dan pengarahan kegiatan, serta evaluasi kegiatan (Adi, 2008).

Dalam mengembangkan sumber daya manusia perempuan pada usaha batu bata di Gampong Ulee Pulo diperlukan suatu wadah untuk membina dan mengarahkan mereka secara rutin. Pelaksanaan pembinaan tersebut merupakan tugas dan kewajiban masyarakat secara bersama-sama dengan membentuk suatu organisasi yang dapat menjadi wadah kepentingan bersama. Ketua Tuha Peuet Gampong mengungkapkan bahwa:

"Strategi dilakukan dengan membentuk organisasi-organisasi masyarakat dan kelompokkelompok usaha masyarakat. Melalui kelompok-kelompok tersebut lebih mudah mamantau dan mengevaluasi setiap perkembangan kualitas sumber daya manusia tiap-tiap kelompok atau organisasi." (Syamsuddin, Gampong Ulee Pulo, 24 September 2020) 
Menurut Kepala Bagian Pemberdayaan pada Dinas Perindustrian, Perdagangan dan Koperasi Kabupaten Aceh Utara, berdasarkan pemantauan yang beliau lakukan beberapa waktu yang lalu, pihak gampong dan Disperindagkop bekerjasama melakukan proses pendataan. Hal ini dilakukan sebagai langkah awal dalam pembinaan perempuan pekerja industri batu bata. Informan menceritakan:

"Pertama-tama melakukan pendataan, kemudian melakukan pembinaan berdasarkan tujuan dari kelompok tersebut. Tujuan pendataan adalah untuk mengetahui berapa dan bagaimana kondisi kelompok usaha tersebut, berapa kelompok usaha batu bata yang masih aktif. Setelah semua terdata dengan baik kelompok tersebut akan dibina secara berkala." (Muzakkar, Gampong Ulee Pulo, 25 September 2020).

Peningkatan kapasitas kelompok dilakukan secara partisipatif dari tahap perencanaan, pelaksanaan, hingga evaluasi. Adapun kelompok perempuan yang dibina hanya kelompok yang selama ini sudah memiliki eksistensi dalam usaha industri batu bata. Hal ini diperoleh berdasarkan hasil wawancara dengan Pendamping Lapangan Kecamatan Dewantara yang mengatakan bahwa:

"Strategi pemberdayaan dalam mengembangkan sumber daya manusia perempuan pada usaha batu bata yaitu melalui pembinaan, tetapi Keuchik hanya membina kelompok usaha yang sudah terbentuk saja, sedangkan masyarakat yang tidak bergabung dalam kelompok tersebut, mereka tidak dibina.” (Supriadi, Gampong Ulee Pulo, 26 September 2020)

\section{b. Pelatihan}

Setelah dilakukan upaya pembinaan, langkah selanjutnya yaitu meningkatkan kapasitas pekerja perempuan dalam industri batu bata. Tingkat keterampilan yang dimiliki oleh setiap perempuan merupakan salah faktor yang perlu diperhatikan dan dipertimbangkan sehingga jenis pekerjaan yang diterimanya dapat terlaksana dengan baik. Hal ini sebagaimana dinyatakan oleh Keuchik Gampong Ulee Pulo sebagai berikut:

"Kami menyelenggarakan pelatihan selama 5 hari. Adapun anggaran yang dialokasikan untuk pembinaan dan pelatihan sebesar Rp. 13.500.000,-. Biaya pelaksanaan semuanya ditanggung dari dana BUMG. Dalam pelatihan dan pembinaan turut dihadirkan tenaga pendamping dari kecamatan dan dibantu oleh aparatur gampong sebagai pengawas yang terdiri dari Keuchik Gampong, Tuha Peut, dan Kepala Urusan Kesejahteraan Sosial. Sedangkan aparatur gampong lainnya bertugas sebagai panitia pelaksana." (Mawardi, Gampong Ulee Pulo, 29 Januari 2020).

Sekretaris Gampong membenarkan pernyataan Keuchik Ulee Pulo di atas sebagaimana disampaikan:

"Pemberdayaan dalam meningkatkan kualitas sumber daya manusia kaum perempuan dalam usaha batu bata dilakukan melalui pelatihan. Sumber dana untuk pelatihan tersebut berasal dari BUMG. Dalam pelatihan tersebut lebih diutamakan untuk meningkatkan pengetahuan dan keterampilan dalam usaha batu bata. Tenaga pendamping dalam pelatihan 
ini berasal dari Kantor Camat Kecamatan Dewantara.” (Sofyan, Gampong Ulee Pulo, 29 Januari 2020).

Mengembangkan sumber daya manusia melalui pelatihan kepada kaum perempuan bermanfaat karena membantu mereka dalam memahami suatu pengetahuan praktis dan penerapannya, guna meningkatkan keterampilan, kecakapan, dan sikap yang diperlukan. Dalam pelatihan tersebut kaum perempuan diberi ilmu pengetahuan dan keterampilan teknis. Adapun peserta pelatihan seperti terlihat pada tabel 1 berikut:

Tabel 1. Nama Peserta Pelatihan

\begin{tabular}{|c|l|c|c|c|}
\hline No. & \multicolumn{1}{|c|}{ Nama Peserta } & Nama Usaha & Lama Pelatihan & Tahun Pelatihan \\
\hline 1 & Kamaliah & UD Berkat & 5 hari & 2017 \\
\hline 2 & Nurbaiti & UD Berkat & 5 hari & 2017 \\
\hline 3 & Safriani & UD Berkat & 5 hari & 2017 \\
\hline 4 & Jamilah & UD Makmur Jaya & 5 hari & 2017 \\
\hline 5 & Ummi Kalsum & UD Makmur Jaya & 5 hari & 2017 \\
\hline 6 & Zubaidah & UD Makmur Jaya & 5 hari & 2017 \\
\hline 7 & Zuraida & UD Usaha Muda & 5 hari & 2017 \\
\hline 8 & Siti Hajar & UD Usaha Muda & 5 hari & 2017 \\
\hline 9 & Faridah & UD Usaha Muda & 5 hari & 2017 \\
\hline 10 & Mariani & UD Sejahtera & 5 hari & 2017 \\
\hline 11 & Saniah & UD Sejahtera & 5 hari & 2017 \\
\hline 12 & Suryawati & UD Sejahtera & 5 hari & 2017 \\
\hline 13 & Fatimah & UD Kana Raseuki & 5 hari & 2017 \\
\hline 14 & Kartini & UD Kana Raseuki & 5 hari & 2017 \\
\hline 15 & Maryam & UD Kana Raseuki & 5 hari & 2017 \\
\hline
\end{tabular}

Sumber: Arsip Gampong Ulee Pulo, 2019

Strategi pemberdayaan perempuan dalam usaha batu bata di Gampong Ulee Pulo yang digunakan adalah strategi penguatan dan penyokongan. Strategi penguatan yakni memperkuat pengetahuan dan kemampuan yang dimiliki ibu rumah tangga dalam memenuhi kebutuhankebutuhannya. Sedangkan strategi penyokongan bertujuan membantu masyarakat untuk mengatasi masalah yang dihadapi terutama dari segi pendapatan dan tingkat kesejahteraan.

Parsons dikutip Suharto (2017) menjelaskan indikator dari suatu pemberdayaan yang dilakukan perlu merujuk pada tiga dimensi, yaitu: (1) Perubahan sosial didorong melalui perubahan individu; (2) Perubahan utama yang ditekankan pada aspek karakter; dan (3) Mengubah strukturstruktur yang menekan kelompok lemah. Pemberdayaan diarahkan guna meningkatkan ekonomi masyarakat secara produktif sehingga mampu menghasilkan nilai tambah yang tinggi dan pendapatan yang lebih besar (Siti Ikramatoun et al., 2020) 
Berdasarkan temuan lapangan, kendala-kendala yang dihadapi dalam melaksanakan pemberdayaan perempuan di Gampong Ulee Pulo diantaranya alokasi anggaran untuk pengembangan sumber daya manusia sangat sedikit, sehingga masyarakat yang memperoleh kesempatan untuk diberdayakan sangat terbatas. Alokasi anggaran untuk pengembangan sumber daya manusia hanya sebesar Rp. 13.500.000,-. Dana tersebut digunakan untuk semua kebutuhan selama pelaksanaan pelatihan yang bersumber dari BUMG yang telah dialokasikan.

Tantangan lain terkait dengan partisipasi masyarakat. Kesediaan masyarakat untuk terlibat menjadi salah satu faktor yang mempengaruhi keberhasilan dari program pemberdayaan. Partisipasi masyarakat bukan hanya melibatkan masyarakat dalam pembuatan keputusan di setiap tahapan program pemberdayaan, namun masyarakat juga dilibatkan dalam mengidentifikasi masalah dan pontesi yang ada. Kendala-kendala yang dihadapi dalam pemberdayaan perempuan pada usaha batu bata di Ulee Pulo yaitu masih banyak kaum perempuan yang menolak berpartisipasi karena disibukkan dengan urusan masing-masing.

\section{KESIMPULAN}

Strategi pemberdayaan perempuan pekerja pengolahan batu bata di Gampong Ulee Pulo Kecamatan Dewantara Kabupaten Aceh Utara dilakukan melalui pembinaan dan pelatihan. Program pemberdayaan tersebut sebagai bentuk penyokongan dan penguatan ekonomi. Penyokongan yaitu memperkuat pengetahuan dan keterampilan pengolahan batu bata. Sedangkan penguatan ekonomi yaitu mampu menyokong para ibu rumah tangga untuk mengatasi masalah

yang dihadapi terutama dari segi pendapatan dan tingkat kesejahteraan. Namun pemerintah masih menghadapi beberapa kendala dalam pemberdayaan perempuan pekerja pengolahan batu bata di Gampong Ulee Pulo. Kendala-kendala tersebut antara lain terbatasnya anggaran untuk pelatihan, serta masih kurangnya kehendak sebagian kaum perempuan untuk berpartisipasi dalam pemberdayaan.

\section{DAFTAR PUSTAKA}

Adi, I. R. (2008). Intervensi Komunitas: Pengembangan Masyarakat sebagai Upaya Pemberdayaan Masyarakat. Jakarta: PT. RajaGrafindo Persada.

Alfiady, T., \& Dewi, R. (2020). Otonomi Khusus dan Kemiskinan di Aceh: Gambaran Kemiskinan Pelaku Usaha Batu Bata di Desa Ulee Pulo Kecamatan Dewantara Kabupaten Aceh Utara. Jurnal Jurnalisme, 9(1), 38-61.

90 | Jurnal Ilmu Sosial dan Ilmu Politik Malikussaleh (JSPM) Volume 2 Nomor 1 Tahun 2021 
Aryani, B. (2017). Peran Perempuan dalam Membantu Ekonomi Keluarga di Desa Tanjung Setia Kecamatan Pesisir Selatan Kabupaten Pesisir Barat (Doctoral dissertation, UIN Raden Intan Lampung).

Asnawi, A., \& M Diah, A. (2013). Model Kebijakan Pengentasan Kemiskinan di Kabupaten Aceh Utara. Ekonomi, Manajemen dan Akuntansi, 2(1), 15-24.

Durkheim, E. (1984). The Division Labour in Society. New York: Palgrave Macmillan.

Husniati, A. M., Maryam, M., \& Zulham, Z. (2018). Post-Mining Areas: Analysis of Women's Involvement in the Informal Sector. In E3S Web of Conferences (Vol. 73, p. 11009). EDP Sciences.

Moleong, L, J. (2014). Metodologi Penelitian Kualitatif. Bandung: Remaja Rosdakarya.

Rahmaharyati, A., Wibhawa, B., \& Nurwati, N. (2017). Peran Ganda Buruh Perempuan Sektor Industri dalam Keluarga. Prosiding Penelitian dan Pengabdian kepada Masyarakat, 4(2).

Siti Ikramatoun, Khairulyadi, \& Riduan. (2020). Pemberdayaan Masyarakat melalui Pengelolaan Hutan Pinus di Kecamatan Linge Aceh Tengah. Jurnal Sosiologi Agama Indonesia (JSAI), 1(3), 238-249. https://doi.org/10.22373/jsai.v1i3.804

Sugiyono (2013). Metode Penelitian Kuantitatif, Kualitatif, dan R \& D. Bandung: Alfabeta.

Suharto, E. (2017). Membangun Masyarakat Memberdayakan Rakyat. Bandung: PT Refika Aditama.

Suhertina, S. \& Darni, D. (2019). Fenomena Double Burden Perempuan Pemulung Muslim dalam Pengelolaan Ekonomi Keluarga. Marwah: Jurnal Perempuan, Agama dan Jender, 17(2), 183-194.

Sumardjo \& Saharuddin (2003). Metode-Metode Partisipatif dalam Pengembangan Masyarakat. Bogor: Institut Pertanian Bogor.

Suyanto, B. \& Sutinah (2015). Metode Penelitian Sosial Berbagai Alternatif Pendekatan. Jakarta: Kencana.

Tjiptaningsih, W. (2018). Pemberdayaan Perempuan dalam Upaya Peningkatan Ekonomi Keluarga (Studi Kasus pada Kelompok Usaha Perempuan di Desa Sindangkempeng Kecamatan Greged Kabupaten Cirebon). REFORMASI: Jurnal Ilmiah Administrasi, 2(1).

Tuwu, D. (2018). Peran Pekerja Perempuan dalam Memenuhi Ekonomi Keluarga: Dari Peran Domestik Menuju Sektor Publik. Al-Izzah: Jurnal Hasil-Hasil Penelitian, 13(1), 63-76.

91 Jurnal Ilmu Sosial dan Ilmu Politik Malikussaleh (JSPM) Volume 2 Nomor 1 Tahun 2021 